\title{
PKM PENGELOLAAN UMKM OTAK-OTAK IKAN TENGGIRI PELABUHAN PAOTERE KECATAMAN UJUNG TANAH MAKASSAR
}

\author{
Syarief Dienan Yahya ${ }^{1,}$ Astuty Hasti ${ }^{2}$
}

\begin{abstract}
Manajemen, Sekolah Tinggi Ilmu Ekonomi YPUP Makassar ri email: dienanyahya@stie.ypup.ac.id Akuntansi, Sekolah Tinggi Ilmu Ekonomi YPUP Makassari2 email: astutyhasti@stie.ypup.ac.id
\end{abstract}

\begin{abstract}
Abstrak
Mitra dalam kegiatan Pengabdian kepada masyarakat ini merupakan UMKM Otak-Otak Ikan Tenggiri Pelabuhan Paotere Kecamatan Ujung Tanah Makassar. Berdasarkan hasil observasi ditemukan bahwa dalam menjalankan usahanya mitra menghadapi beberapa hambatan permasalahan pada beberapa aspek yaitu ( 1) Aspek Manajemen, (2) Aspek Produksi, (3) Aspek Sumber Daya Manusia. Kegiatan pengabdian masyarakat ini secara umum menggunakan pendekatan partisipatoris melalui pelibatan mitra secara aktif dalam perancangan metode pelaksanaan kegiatan. Hal ini dilakukan agar kegiatan yang dilaksanakan dapat tepat sasaran. Pendekatan brainstorming, observasi, dan diskusi mendalam juga dilakukan guna memperoleh informasi yang lebih valid dalam memformulasikan solusi dari permasalahan yang dialami mitra. Fokus dari kegiatan pengabdian kepada masyarakat ini meliputi pengelolaan manajemen UMKM yang terdiri dari penyusunan job description karyawan untuk berbagai kegiatan lini produksi, redesain dan rebranding produk, online selling, sistem pembukuan, pengadaan alat produksi berkapasitas besar, serta workshop, pelatihan dan pendampingan dalam melakukan penjualan dan transaksi menggunakan mobile banking. Di akhir kegiatan diharapkan target luaran yang dihasilkan meliputi: peningkatan pengetahuan, peningkatan keterampilan, peningkatan kualitas produk, peningkatan jumlah produk, peningkatan jenis produk, peningkatan kapasitas produksi, pemasaran antar pulau, peningkatan aset, peningkatan omset, peningkatan kemampuan manajemen, dan peningkatan keuntungan mitra. Target luaran tersebut diukur melalui beberapa indikator keberhasilan dan pencapaian luaran secara kuantitatif, sehingga keberhasilan program ini dapat dengan mudah untuk diukur.
\end{abstract}

Kata Kunci: Mobile Banking; Akuntansi UMKM; Olahan Ikan; Otak-otak.

\section{Abstract}

Partners in this community service activity are the Micro, Small and Medium Enterprises of Mackerel Grilled fish cake, Paotere Port, Ujung Tanah District, Makassar. Based on observations, it was found that in running their business partners faced several aspects problems, (1) Management Aspects, (2) Production Aspects, (3) Human Resources Aspects. This community service activity generally uses a participatory approach through the active involvement of partners in the design of methods for implementing activities. The approach is used to the activities programs can be right on target. The approach of brainstorming, observation, and in-depth discussion was also used in order to obtain more valid information in formulating solutions to the problems experienced by partners. The focus of this community service activity includes the management of MSME which consists of preparing employee job descriptions for various production line activities, product redesign and rebranding, online selling, bookkeeping systems, procurement of large capacity production equipment, as well as workshops, training and assistance in making sales and transactions using mobile banking. At the end of the activity, it is expected that the output targets produced include: increasing knowledge, increasing skills, improving 
product quality, increasing the number of products, increasing product types, increasing production capacity, inter-island marketing, increasing assets, increasing turnover, increasing management capabilities, and increasing partner profits. . The output targets are measured through several indicators of success and quantitative output achievements, so that the success of this program can be easily measured.

Keywords: Mobile banking; MSME accounting; Processed Fish; Grilled fish cake

\section{PENDAHULUAN}

Tidak dapat dipungkiri bahwa Indonesia sebagai negara kepulauan yang sebagian besar wilayahnya didominasi oleh bentangan perairan dimana luas lautannya lebih besar dari luas daratan, hal ini menjadikan Indonesia sebagai salah satu negara dengan bentangan garis pantai terpanjang didunia dengan 99.093 kilometer. Selain itu Indonesia juga tersusun oleh 17.0oo pulau yang tersebar, bahkan saat ini hanya sebanyak 3.000 dari pulau tersebut belum teridentifikasi dan memiliki nama atau direkam data koordinatnya. Dengan potensi kelautan yang dimilikinya pengoptimalan nilai tambah hasil kelautan dan perikanan melalui industrialisasi menjadi salah satu solusi dalam mewujudkan kesejahteraan masyarakat dan penguatan daya saing nasional.

Sebagai salah satu kota di Indonesia Timur yang terletak di pesisir barat daya Pulau Sulawesi dan berbatasan langsung dengan Selat Makassar, potensi hasil laut di Kota Makassar sangat melimpah, pengolahan hasil laut dari pelaku Usaha Menegah Kecil Mikro (UMKM) kota Makassar masih menjadi salah satu komoditi primadona konsumen baik wisatawan domestik maupun wisatawan mancanegara yang berkunjung. Selain itu keberadaan Pelabuhan Paotere yang terletak di Kecamatan Ujung Tanah Kota Makassar sebagai salah warisan dan saksi kejayaan maritim Kerajaan Gowa Tallo dimasa lalu yang menjadi pusat niaga dan pelabuhan legendaris yang bersejarah sampai saat ini, Pelabuhan Paotere masih berperan vital dalam jantung perekonomian masyarakat pinggiran kota Makassar di tengah kerasnya persaingan dan impitan ekonomi.

Masyarakat di sekitar pelabuhan sangat mengandalkan hasil laut sebagai nadi perekonomian tidak hanya dari hasil tangkapan nelayan melainkan juga dari olahan hasil laut dari para nelayan, salah satu olahan laut yang sangat digemari masyarakat saat ini adalah otakotak ikan tenggiri. Mitra dalam kegiatan Program Kemitraan Masyarakat (PKM) yang diusulkan merupakan pengusaha Usaha kecil Mikro pembuat otak - otak olahan ikan tenggiri yang terletak di seputar Pelabuhan Paotere Kecamatan Ujung Tanah Kota Makassar.

Produksi dari Mitra dalam kegiatan Program Kemitraan Masyarakat (PKM) ini adalah otak - otak ikan tenggiri seperti yang tampak pada gambar berikut:
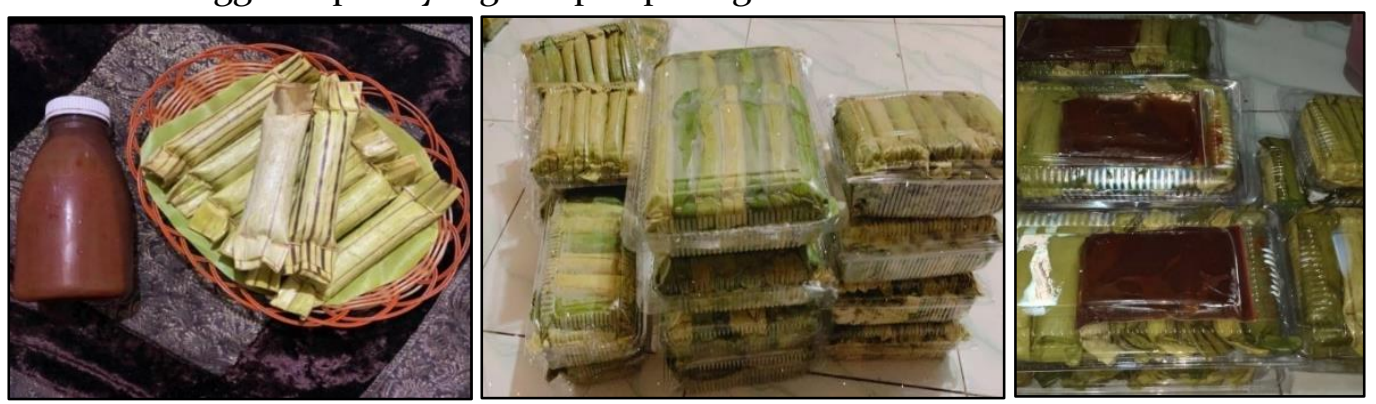

Gambar 1: Otak-otak Ikan Tenggiri 
Berdasarkan hasil observasi diketahui bahwa otak -otak ikan tenggiri tersebut dijual dengan harga satuan Rp. 3.50o,- tanpa merek yang kemudian didistribusikan ke konsumen. Biasanya konsumen membeli untuk dikonsumsi sendiri maupun disajikan dalam berbagai acara hajatan (pernikahan, syukuran dan lainnya), selain itu konsumen tetap mitra juga berasal dari beberapa restoran ternama yang tersebar di dalam maupun luar kota Makassar, tidak jarang terdapat beberapa konsumen yang memesan untuk dikirim ke berbagai kota sebagai oleh-oleh khas Makassar.

Setiap harinya mitra dapat memproduksi sebanyak 2.50o buah otak-otak dengan memberdayakan 5 sampai dengan 10 orang tenaga kerja yang didominasi oleh ibu-ibu nelayan sekitar pelabuhan Paotere yang dapat bertambah sebanyak 2 sampai 3 orang tenaga kerja tambahan apabila mitra memiliki pesanan yang banyak. Dalam setiap harinya mitra menghabiskan sebanyak $15 \mathrm{~kg}$ daging ikan Tenggiri yang dapat meningkat di hari-hari tertentu tergantung dari permintaan pasar seperti hari libur, bulan Ramadhan dan beberapa acara hajatan, hal tersebut tidak jarang membuat mitra kewalahan dalam melayani permintaan pesanan karena keterbatasan alat produksi yang dimiliki.

Hasil wawancara juga diketahui bahwa alasan mitra menjalankan usaha ini karena mitra melihat permintaan pasar terhadap otak-otak ikan tenggiri sebagai makanan pelengkap khas dari Kota Makassar semakin digemari dari berbagai kalangan masyarakat, terlebih lagi banyak dari usaha restoran ternama di dalam dan di luar di Kota Makassar menjadikan otak-otak sebagai menu andalan khususnya restoran seafood yang semakin berkembang di Makassar. Selain itu perkembangan kota Makassar yang semakin menarik minat wisatawan domestik maupun mancanegara yang berkunjung atau hanya sekedar singgah dan mencari oleh-oleh juga mendasari mitra menjalankan usaha ini. Selanjutnya menurut mitra, dari usaha ini juga beberapa masyarakat sekitar pelabuhan menggantungkan perekonomiannya dalam memenuhi kebutuhan hidup sehari-harinya.

Seperti yang telah dipaparkan sebelumnya bahwa bahan baku dari pembuatan otak-otak berasal dari ikan tenggiri yang diperoleh dari para nelayan pelabuhan Paotere yang merupakan salah satu pelabuhan ikan populer di Makassar. Selain cita rasa ikan tenggiri yang khas, ikan tenggiri juga mengandung berbagai macam nutrisi yang menyehatkan untuk dikonsumsi seperti omega-3, protein dan mineral (zat besi, fosfor, zinc, selenium dan yodium). Selain itu akses ke lokasi pelabuhan yang dekat sangat memudahkan mitra dalam memperoleh bahan baku dalam memproduksi otak-otak. Namun di musim-musim tertentu hasil tangkapan nelayan kadang tidak menentu membuat harga bahan baku menjadi kian fluktuatif sehingga menyulitkan mitra dalam memproduksi dan mempertahankan harga dan permintaan konsumen.

Proses produksi otak-otak diawali dengan memisahkan tulang ikan dan daging secara manual kemudian dicuci bersih dilanjutkan dengan proses penggilingan daging ikan sampai halus lalu dicampurkan dengan air santan, setelah proses pencampuran 
sudah merata adonan ditempatkan di dalam wadah untuk diberi tepung terigu dan bumbu penyedap untuk dicampur sampai mengembang. Setelah itu adonan di bungkus kecil-kecil dengan daun pisang. Otak-otak yang telah terbungkus kemudian dikukus selama 5 sampai dengan 10 menit. Proses terakhir otak-otak dikemas untuk selanjutnya dijual kepada konsumen.

Sistem pemasaran mitra selama ini dilakukan secara langsung (direct selling) kepada konsumen yang terdiri dari restoran baik di dalam dan diluar kota Makassar, selain itu terdapat pula konsumen yang memesan untuk dikonsumsi pribadi maupun untuk hajatan (pernikahan atau syukuran). Model pemasaran ini masih tergolong pasif karena hanya menunggu konsumen memesan hal ini dilakukan untuk menghindari otak-otak rusak karena mitra belum memiliki freezer box yang cukup untuk menyimpan persediaan otak-otak. Hal ini bila dibiarkan terus menerus dalam jangka panjang akan membuat mitra kehilangan konsumen.

Sistem pengelolaan usaha yang diterapkan pada usaha mitra masih dikelola secara tradisional dimana pengelolaan usaha masih dikelola sendiri oleh pemilik usaha dengan memberdayakan ibu-ibu di sekitar pelabuhan Paotere, selain itu belum adanya proses pembagian kerja (division of labor) sehingga setiap pekerja belum memiliki tugas yang jelas sehingga membuat pekerja dapat berganti-ganti tugas dalam bekerja, hal ini dapat memperlambat proses produksi karena karyawan perlu memahami suatu tugas dan membutuhkan waktu untuk menjadi mahir setelah dia berulang -ulang melakukan pekerjaan tersebut. Pola permintaan otak-otak yang bersifat fluktuatif membuat mitra tidak memiliki persediaan bahan baku yang cukup karena mitra belum memiliki peralatan yang memadai dalam menyimpan bahan baku dalam jumlah yang cukup banyak sehingga lonjakan permintaan harus disesuaikan dengan arus bahan baku yang tersedia dari nelayan. Peralatan yang digunakan dalam proses produksi masih sederhana dan masih ditemukan beberapa peralatan produksi yang belum sesuai dengan standar produksi untuk digunakan dalam skala yang lebih besar.

Dalam menjalankan usahanya selama ini mitra menggunakan modal sendiri yang berasal dari tabungan dan dana pribadi, hal ini menyulitkan mitra dalam mengatasi lonjakan permintaan produk, tidak jarang dalam mengatasi hal tersebut mitra menggunakan pinjaman modal dari dana pihak ketiga untuk memenuhi permintaan dan menjaga ketersediaan bahan baku.

Proses pencatatan transaksi mitra juga dilakukan secara sederhana sehingga mitra belum bisa menghitung pencatatan keuntungan dan kerugian pasti dari fluktuasi harga bahan baku dan permintaan konsumen, selama hasil penjualan otak-otak dapat membayar karyawan dan menutupi harga bahan baku dianggap sudah cukup oleh mitra. Permasalahan pada pengelolaan UMKM yang masih konvensional, Hal ini terlihat dari belum jelasnya pembagian kerja dari para karyawan dikarenakan masih ditemui karyawan yang masih belum memiliki tugas yang jelas, pembagian kerja hanya didasarkan pada tahapan pekerjaan yang sedang berlangsung. Selain itu produk yang 
dihasilkan belum memiliki identitas yang jelas hal ini tampak dari kemasan produk yang belum menunjukkan brand identity yang dapat dengan mudah di identifikasi oleh konsumen. Selain itu proses pemasaran produk juga masih dilakukan secara konvensional melalui direct selling dan belum memanfaatkan media internet atau online selling dalam memasarkan produknya. Pencatatan dan pembukuan keuangan juga masih dilakukan dengan cara konvensional hal ini terlihat dari pengetahuan mitra yang masih minim tentang pencatatan dan pembukuan keuangan maupun pesanan, selain itu mitra belum memahami konsep break event point sehingga mitra masih mengalami kesulitan dalam melakukan perhitungan harga jual yang diakibatkan lonjakan harga bahan baku maupun perubahan variabel lainnya yang dapat mempengaruhi harga jual.

Dari aspek produksi terlihat bahwa peralatan yang digunakan mitra dalam memproduksi otak-otak masih minim dan berkapasitas kecil, sehingga dapat mempengaruhi kuantitas produksi yang bila dibiarkan secara berkepanjangan dapat berdampak pada penurunan pelanggan. Selain itu suplai bahan baku juga masih mengandalkan hasil tangkapan dari nelayan hal ini mengakibatkan mitra kesulitan dalam melayani lonjakan pesanan karena belum tersedianya penyimpanan freezer box yang cukup dalam menampung daging ikan tenggiri dari nelayan.

Dari aspek sumber daya manusia terlihat bahwa masih minimnya pengetahuan pengelolaan usaha dari mitra sehingga dapat menghambat perkembangan usaha kedepannya. Berdasarkan hasil observasi potensi pengembangan usaha ini masih sangat besar sehingga pengetahuan dan pemahaman terhadap informasi pasar, selera pasar, potensi pesaing dan brand position sangat penting untuk dimiliki mengingat banyaknya keluarga di sekitar pelabuhan Paotere yang menggantungkan hidupnya pada usaha ini. Sasaran dari kegiatan pengabdian ini adalah mengembangkan pengelolaan UMKM mitra melalui kegiatan transfer pengetahuan, workshop, pendampingan, peningkatan kapasitas produksi, pelatihan, monitoring secara berkala. Mitra dalam kegiatan Program Kemitraan Masyarakat (PKM) ini merupakan pengusaha Usaha kecil Mikro pembuat otak - otak olahan ikan tenggiri yang terletak di seputaran Pelabuhan Paotere Kecamatan Ujung Tanah Kota Makassar lokasi kegiatan dilaksanakan di Jalan Sabutung Raya No.8o Kec. Ujung Tanah, Kota Makassar.

\section{METODE}

Dalam melaksanakan kegiatan pengabdian masyarakat ini secara umum tim pengusul menggunakan pendekatan partisipatoris melalui pelibatan mitra secara aktif dalam perancangan metode pelaksanaan kegiatan. Hal ini dilakukan agar kegiatan yang dilaksanakan dapat tepat sasaran. Pendekatan brainstorming, observasi, dan diskusi mendalam juga dilakukan guna memperoleh informasi yang lebih valid dalam memformulasikan solusi dari permasalahan yang dialami mitra, secara detail deskripsi langkah-langkah yang dilakukan dalam metode pelaksanaan yang telah dilakukan antara lain adalah: (1) Survei Awal dilakukan untuk sosialisasi dan mendiskusikan jadwal 
pengabdian kepada masyarakat pada kelompok mitra (2) Wawancara dilakukan untuk menggali informasi mengenai tahapan produksi dan pembagian kerja yang digunakan dalam penyusunan Job description dan Standar Operasional Prosedur.

Selain itu masukan dan nilai produk juga digali pada tahapan ini, yang selanjutnya akan dituangkan dalam desain kemasan dan branding produk mitra. (3) Penyusunan instrumen solusi aspek manajemen. Pada tahapan ini tim bekerja dengan melakukan penyusunan Job description dan Standar Operasional Prosedur dilanjutkan dengan perancangan desain kemasan dan branding produk sesuai dengan nilai-nilai perusahaan yang diingin kan mitra. Di tahapan ini juga tim pengusul menyusun skema penjualan online dan rancangan sistem pembukuan untuk mitra (4) Diseminasi solusi permasalahan. Pada tahapan ini tim pengusul menjabarkan hasil penyusunan instrumen solusi aspek manajemen berupa jabaran Job description dan Standar Operasional Prosedur beserta pelatihan pembukuan transaksi keuangan kepada mitra.

Pada tahapan ini juga tim pengusul menyerahkan hasil desain produk untuk dapat diaplikasikan pada produk otak-otak yang telah diproduksi. Selain itu juga tim pengusul memberikan akun penjualan online kepada mitra untuk dapat digunakan menerima permintaan pembelian konsumen. (5) Peningkatan produksi melalui penggunaan alay produksi berstandar industry dan berkapasitas besar kepada mitra dalam menunjang aktifitas usaha. (6) Pelatihan dan pendampingan. Sebagai tindak lanjut atas diseminasi yang telah dilakukan akan dilakukan monitoring yang intens guna mengidentifikasi permasalahan dan kendala yang dihadapi mitra dalam pengaplikasian solusi yang telah diberikan sebelumnya.

\section{HASIL DAN PEMBAHASAN}

Hasil dari kegiatan pengabdian ini terdiri dari beberapa aspek yang mencadi focus pengembangan mitra antara lain sebagai berikut:

\section{Aspek Manajemen}

Dari aspek manajemen terdapat beberapa dampak peningkatan mitra antara lain melalui penerapan proses pembagian kerja (division of labor) sehingga setiap pekerja belum memiliki tugas yang jelas sehingga membuat pekerja dapat berganti-ganti tugas dalam bekerja, hal ini dapat memperlambat proses produksi karena karyawan perlu memahami suatu tugas dan membutuhkan waktu untuk menjadi mahir setelah dia berulang -ulang

melakukan pekerjaan tersebut. Sebelumnya proses pembagian kerja hanya didasarkan pada tahapan pekerjaan yang sedang berlangsung. Setelah kegiatan dan proses pendampingan tampak bahwa pembagian kerja semakin terarah dan proses kerja semakin efektif dan efisien walaupun di awal membutuhkan proses penyesuaian sebelumnya, hal ini terlihat dengan semakin berkurangnya produk cacat selama kegiatan pendampingan.

Pembuatan desain kemasan akan disesuaikan dengan konsep dan prinsip yang diusung oleh mitra sehingga tampilan kemasan dapat merepresentasikan pesan kepada konsumen melalui kemasan produk, selain itu informasi kontak untuk pemesanan juga disertakan pada kemasan otak-otak. Selain melindungi, kemasan juga dapat menjadi media iklan yang efektif, kemasan yang baik setidaknya dapat menyampaikan pesan kepada konsumen untuk menginformasikan, mengingatkan, menambah nilai dan membantu mengenali produk. Meskipun dalam pelaksanaannya desain kemasan produk masih sederhana namun terbukti efektif meningkatkan penjualan hal ini ditunjukkan dengan pesanan dari konsumen setelah melihat informasi pada kemasan produk. Selain itu kemasan saos yang sebelumnya hanya dibungkus plastik rentan bocor dan dapat merusak produk sebelum sampai ke tangan konsumen diganti dengan penggunaan botol yang lebih tahan bocor.
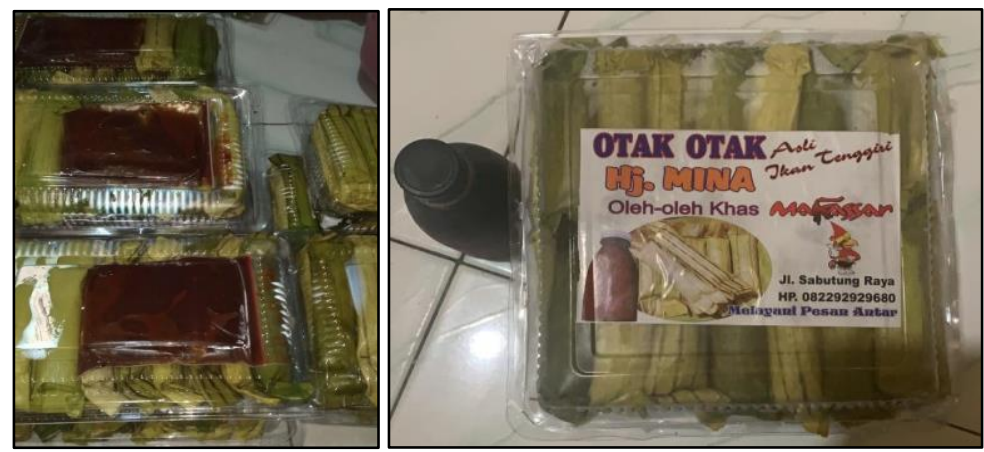

\section{Gambar 2: Kemasan Produk Sebelum dan Setelah Pelaksanaan Kegiatan}

Mengoptimalkan media internet dalam mempromosikan produk dipasar. Sistem penjualan online juga akan diterapkan guna meningkatkan pemasaran di masyarakat. Sehingga arus informasi dapat lebih luas untuk dilakukan yang dulunya hanya melalui penjualan langsung diharapkan melalui media sosial seperti Instagram, facebook, dan media pendukung lainnya diharapkan akan menambah ekspansi pangsa pasar produk sehingga jumlah pesanan dari luar pulau dapat meningkat.

\section{Aspek Produksi}

Selain aspek manajemen melalui kegiatan ini juga dilaksanakan peningkatan kapasitas produksi dalam rangka mendorong kuantitas dan kualitas hasil produksi mitra kedepannya. Dilakukan peningkatan kapasitas produksi dengan melakukan pengadaan alat-alat produksi berkaspasitas besar antara lain, panci pengukusan berukuran besar, 
freezer box yang dapat bekerja pada suhu minus 15 derajat dengan keterangan indikator suhu yang memudahkan pengoperasian dan beberapa alat produksi penunjang lainnya.

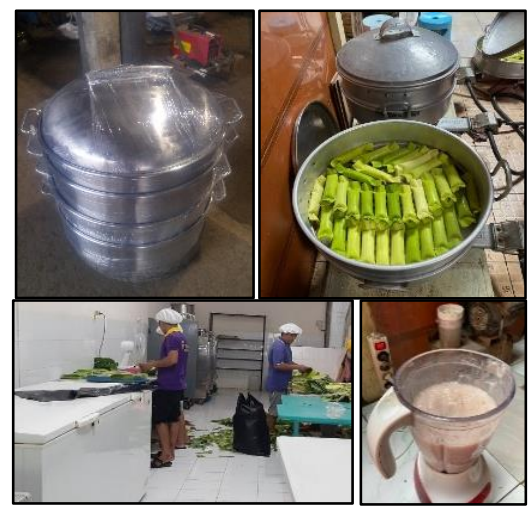

Gambar 3: Penggunaan Alat Produksi Berkapasitas Besar Pada Mitra

Selain penggunaan alat produksi berkapasitas besar sistem produksi juga dilakukan perbaikan guna peningkatan efektifitas dan efesiensi produksi, dengan penerapan sistem produksi dan model persediaan yang tepat lonjakan permintaan pada hari-hari tertentu seperti hari raya dapat sedikit diatasi, ilustrasi sistem produksi dapat dilihat pada gambar berikut ini :

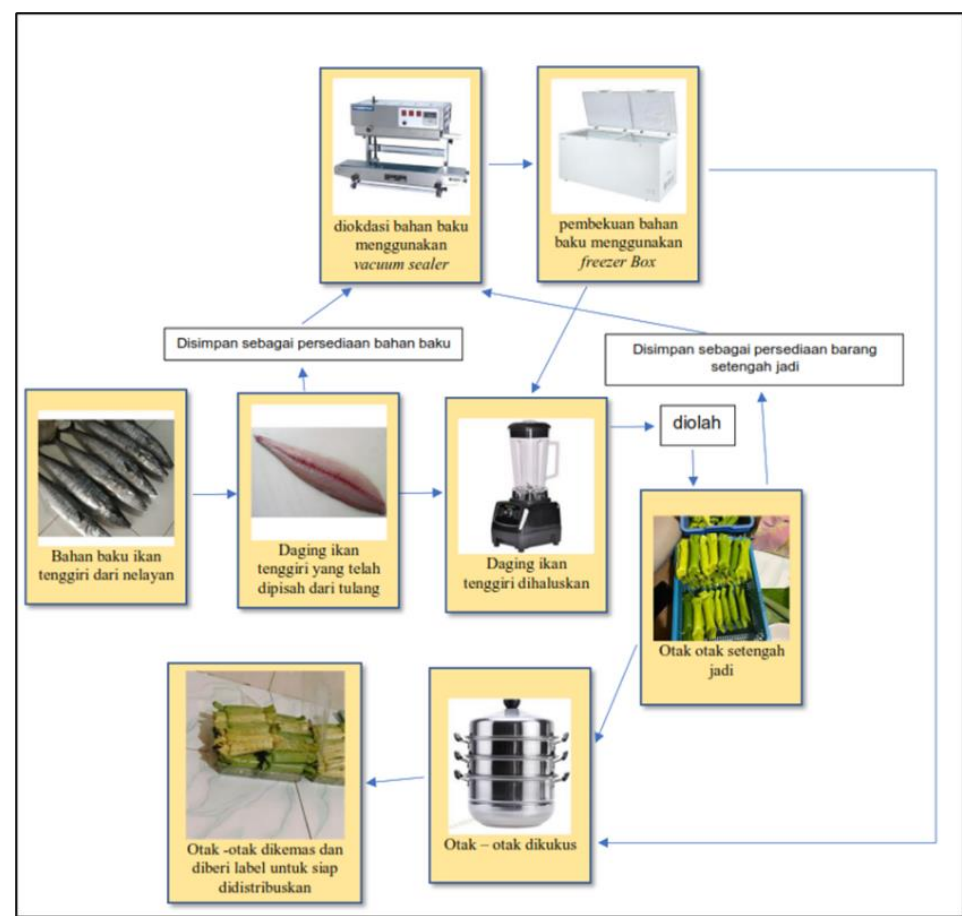

Gambar4 : Pengembangan Sistem Produksi Mitra Setelah Kegiatan

\section{Aspek Sumber Daya Manusia}

Peningkatan kemampuan tentang kewirausahaan melalui kegiatan pendampingan secara berkala selama kurun waktu kegiatan. Dalam kegiatan pendampingan ini mitra akan dibekali dengan pengetahuan tentang pengelolaan usaha. Selain itu mitra juga akan diarahkan menggunakan internet banking/ mobile banking sehingga dapat mempermudah transaksi online, penggunaan teknologi ini diharapkan 
dapat meningkatkan performa UMKM mitra kedepannya. Selain itu mitra melalui kegiatan pendampingan senantiasa didorong untuk melakukan upaya untuk memproduksi produk olahan alternatif selain otak-otak dan saat ini mitra sedang mempertimbangkan untuk memproduksi olahan ikan ternggiri berupa bakso ikan.
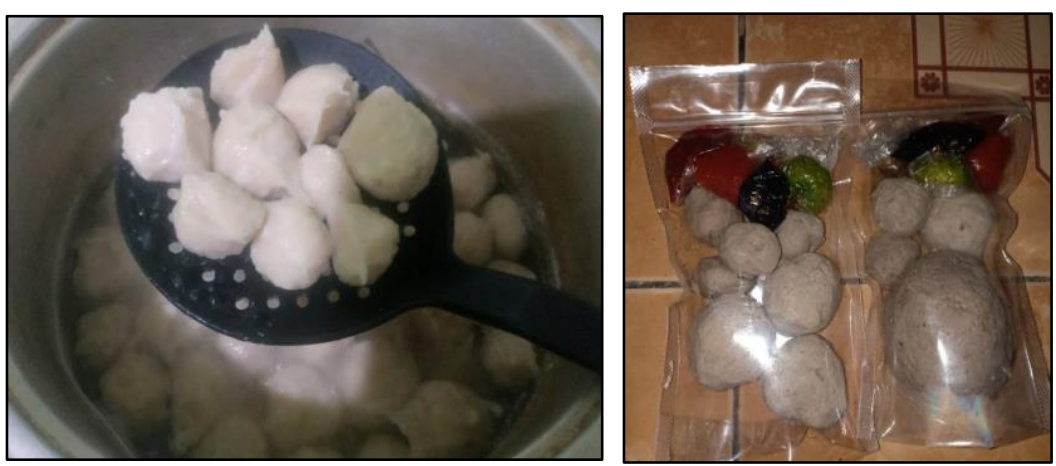

Gambar 5: Produk Olahan Alternatif Oleh Mitra

Secara ringkas gambaran outcome yang dirasakan oleh mitra disajikan dalam tabel berikut ini :

Tabel 1: Rekapitulasi Outcome Kegiatan Pengabdian

\begin{tabular}{|c|c|c|c|c|}
\hline Aspek & Sebelum Kegiatan & Solusi & Luaran & Setelah Kegiatan \\
\hline \multirow{4}{*}{$\begin{array}{c}\text { Aspek } \\
\text { Manajemen }\end{array}$} & 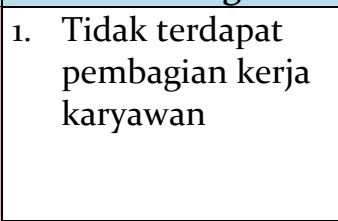 & $\begin{array}{l}\text { 1. Merancang pembagian } \\
\text { kerja dan Standar } \\
\text { Operasional Prosedur } \\
\text { (SOP) }\end{array}$ & $\begin{array}{l}\text { - Job desk } \\
\text { karyawan } \\
\text { - SOP }\end{array}$ & $\begin{array}{l}\text { - Pembagian dan } \\
\text { spesifikasi kerja } \\
\text { karyawan } \\
\text { - Produk cacat } \\
\text { berkurang 50\% }\end{array}$ \\
\hline & $\begin{array}{l}\text { 2. Kemasan produk } \\
\text { otak-otak masih } \\
\text { sederhana }\end{array}$ & $\begin{array}{l}\text { 2. Membuat desain } \\
\text { kemasan dan branding } \\
\text { produk otak-otak }\end{array}$ & $\begin{array}{r}\text { - Pemasangan } \\
\text { label produk }\end{array}$ & $\begin{array}{l}\text { - Produk telah } \\
\text { berlabel 100\% }\end{array}$ \\
\hline & $\begin{array}{l}\text { 3. } \text { pemasaran } \\
\text { produk masih } \\
\text { konvensional } \\
\end{array}$ & $\begin{array}{l}\text { 3. Sistem penjualan } \\
\text { online }\end{array}$ & $\begin{array}{l}\text { - Transaksi } \\
\text { penjualan } \\
\text { online }\end{array}$ & $\begin{array}{l}\text { - Peningkatan } \\
\text { pesanan antar } \\
\text { Pulau }\end{array}$ \\
\hline & $\begin{array}{ll}\text { 4. } & \text { Sistem } \\
\text { pembukuan } \\
\text { penjualan masih } \\
\text { dilakukan secara } \\
\text { konvensional }\end{array}$ & $\begin{array}{l}\text { 4. Perancangan sistem } \\
\text { pembukuan }\end{array}$ & $\begin{array}{l}\text { sistem } \\
\text { pembukuan } \\
\text { sederhana }\end{array}$ & $\begin{array}{l}\text { - } 100 \% \text { jumlah } \\
\text { transaksi } \\
\text { tercatat dengan } \\
\text { baik }\end{array}$ \\
\hline \multirow{4}{*}{$\begin{array}{c}\text { Aspek } \\
\text { Produksi }\end{array}$} & $\begin{array}{l}\text { 1. Panci kukus yang } \\
\text { berukuran kecil }\end{array}$ & $\begin{array}{l}\text { 1. alat kukus yang } \\
\text { berukuran lebih besar }\end{array}$ & $\begin{array}{l}\text { Kapasitas } \\
\text { produksi } \\
\text { meningkat }\end{array}$ & $\begin{array}{l}\text { Jumlah otak otak } \\
\text { yang dapat } \\
\text { dikukus } \\
\text { meningkat } 100 \%\end{array}$ \\
\hline & $\begin{array}{l}\text { 2. Ukuran blender } \\
\text { penghalus daging } \\
\text { yang masih kecil }\end{array}$ & $\begin{array}{l}\text { 2. Pengadaan blender } \\
\text { penghalus daging yang } \\
\text { lebih besar }\end{array}$ & $\begin{array}{l}\text { Kapasitas } \\
\text { produksi } \\
\text { meningkat }\end{array}$ & $\begin{array}{l}\text { Jumlah daging } \\
\text { yang dapat } \\
\text { dihaluskan } \\
\text { meningkat } 100 \% \\
\end{array}$ \\
\hline & $\begin{array}{l}\text { 3. Lemari pendingin } \\
\text { daging yang } \\
\text { masih kecil } \\
\end{array}$ & $\begin{array}{l}\text { 3. Pengadaan freezer box } \\
\text { berkapasitas besar }\end{array}$ & $\begin{array}{l}\text { Kapasitas } \\
\text { produksi } \\
\text { meningkat }\end{array}$ & $\begin{array}{l}\text { Jumlah persediaan } \\
\text { bahan baku } \\
\text { meningkat } 200 \%\end{array}$ \\
\hline & $\begin{array}{l}\text { 4. } \text { Tidak terdapat } \\
\text { vacuum sealer }\end{array}$ & $\begin{array}{l}\text { 4. Pengadaan vacuum } \\
\text { sealer }\end{array}$ & $\begin{array}{l}\text { Peningkatan } \\
\text { kualitas } \\
\text { produksi }\end{array}$ & $\begin{array}{l}\text { Usia bahan baku } \\
\text { meningkat 200\% }\end{array}$ \\
\hline $\begin{array}{l}\text { Aspek } \\
\text { Sumber }\end{array}$ & $\begin{array}{l}\text { Pengetahuan } \\
\text { tentang }\end{array}$ & $\begin{array}{l}\text { 1. Pelatihan dan } \\
\text { pendampingan }\end{array}$ & $\begin{array}{l}\text { Peningkatan } \\
\text { pengetahuan }\end{array}$ & $\begin{array}{l}\text { Penggunaan } \\
\text { internet banking / }\end{array}$ \\
\hline
\end{tabular}




\begin{tabular}{|c|l|l|l|l|}
\hline Aspek & Sebelum Kegiatan & \multicolumn{1}{|c|}{ Solusi } & \multicolumn{1}{c|}{ Luaran } & Setelah Kegiatan \\
\hline $\begin{array}{c}\text { Danus } \\
\text { Manusia }\end{array}$ & $\begin{array}{l}\text { kewirausahaan yang } \\
\text { masih kurang }\end{array}$ & kewirausahaan & $\begin{array}{l}\text { tentang } \\
\text { kewirausahaan }\end{array}$ & $\begin{array}{l}\text { mobile banking } \\
\text { pada transaksi }\end{array}$ \\
\cline { 2 - 5 } & $\begin{array}{l}\text { Masih minimnya } \\
\text { pengetahuan } \\
\text { tentang produk } \\
\text { olahan alternatif }\end{array}$ & $\begin{array}{l}\text { 2. Pelatihan produk } \\
\text { alternatif }\end{array}$ & $\begin{array}{l}\text { Peningkatan } \\
\text { kapasitas } \\
\text { produksi }\end{array}$ & $\begin{array}{l}\text { Variasi produk } \\
\text { yang ditawarkan } \\
\text { meningkat 100\% }\end{array}$ \\
\hline
\end{tabular}

\section{KESIMPULAN}

Selama pelaksanaan kegiatan pengabdian yang dilaksanakan baik pada saat observasi awal hingga saat berlangsungnya pelatihan dan pendampingan, tampak bahwa kegiatan pengabdian kepada masyarakat ini sangat diminati dan sangat diapresiasi oleh masyarakat khususnya pada situasi pandemi saat ini. Peran perguruan tinggi melalui transfer pengetahuan dan bersentuhan langsung dengan masyarakat sangat dibutuhkan dalam mendorong roda perekonomian khususnya pada industri mikro. Pelaksanaan kegiatan serupa juga sangat diharapkan oleh masyarakat untuk dilaksanakan setiap tahunnya sehingga pengetahuan masyarakat akan pengelolaan usaha mikro semakin meningkat dan diharapkan dapat meningkatkan taraf hidup masyarakat sekitar.

Melalui kegiatan pengabdian ini terdapat beberapa saran yang dapat dijadikan bahan evaluasi terhadap kegiatan serupa dimasa yang akan datang antara lain dalam pelaksanaan kegiatan pendampingan sebaiknya mempertimbangkan penggunaan bahasa yang lebih mudah dipahami oleh masyarakat awam dengan menghindari penggunaan kosakata yang terlalu akademik sehingga masyarakat dapat memahami konteks pembicaraan.

Selain itu, program pembinaan pada usaha mikro tidak dapat dievaluasi dengan melihat pencapaian jangka pendek saja namun pencapaian jangka panjang juga sangat dibutuhkan, maka dari itu keberlangsungan pendampingan melalui proses monitoring pasca kegiatan sangat berperan, dan pelaksanaan kegiatan serupa dapat secara rutin dilaksanakan setiap tahunnya. Rencana pengembangan dari kegiatan ini akan tetap dilakukan pendampingan kepada mitra meskipun kegiatan telah berakhir melalui program pembinaan dari perguruan tinggi yang di mediasi oleh Lembaga Penelitian dan Pengabdian Masyarakat (LPPM) STIE YPUP Makassar dimana saat ini tim sedang melakukan kegiatan pendampingan untuk dapat mengakses sarana permodalan usaha mikro dari lembaga perbankan.

Selanjutnya, langkah strategis saat ini yang ditempuh berusaha direalisasikan melalui peningkatan pemasaran dan pengelolaan usaha otak-otak dengan memberikan edukasi tentang peranan media digital dalam meningkatkan usaha khususnya usaha mikro, diharapkan dengan semakin mahirnya mitra dalam penggunaan teknologi digital ini dapat meningkatkan performa usaha, selain itu peningkatan aset juga dapat membantu mitra dalam memperoleh akses permodalan usaha kedepannya sehingga dapat melakukan ekspansi usaha lebih luas lagi. 


\section{UCAPAN TERIMA KASIH}

Ucapan terima kasih disampaikan kepada segenap pihak yang telah mendukung terlaksananya kegiatan pengambdian masyarakat ini sehingga dapat terlaksana sebagaimana mestinya ditengah sulitnya situasi pandemi covid-19 yang melanda Indonesia. Ucapan terima kasih juga disampaikan kepada Direktorat Riset dan Pengabdian Masyarakat Direktorat Jenderal Riset dan Pengembangan Kementerian Riset, Teknologi, dan Pendidikan Tinggi atas dukungannya mendanai kegiatan ini melalui hibah Pengabdian Kepada Masyarakat Kompetitif Nasional skema Program Kemitraan Masyarakat tahun anggaran 2021. 


\section{REFERENSI}

Achmad Mun' im Ramadhan, M. Syaharudin, Ema Desia Prajitiasari. (2015). Pengaruh Penerapan SOP (Standard Operating Procedure) dan Sistem Penghargaan (Reward System) Terhadap Produktivitas Kerja Pada Karyawan Bagian Distribusi PT Unirama Duta Niaga Surabaya. Jurusan Manajemen, Fakultas Ekonomi, Universitas Jember.

A. Shimp, Terence. (2014). Komunikasi Pemasaran Terpadu dalam periklanan dan Promosi. Jakarta: Salemba Empat.

Astuty Hasti. (2016). Audit Manajemen Atas Fungsi Keuangan Pada PT. PLN (Persero) Kantor Cabang Makassar. Jurnal Ilmiah AKMEN vol.13 no. 2, hal. 344-352. ISSN 18298524 .

Habibatun Naimah, Ika Junia Ningsih. (2014). Proses Pembekuan Ikan Katamba (Lethrinus Lentjan) Produk WGGS (Whole Gilled Gutted Scaled). Samakia: Jurnal Ilmu Perikanan Volume 5, No. 2, Agustus 2014 ISSN: 2086-3861

Rahmadana. S. (2013). Analisa Masa Simpan Rendang Ikan Tuna Dalam Kemasan Vakum Selama Penyimpanan Pada Suhu Ruang dan Dingin. Program Studi Ilmu dan Teknologi Pangan Jurusan Teknologi Pertanian Fakultas Pertanian Universitas Hasanuddin Makassar.

Syarief Dienan Yahya, Harry Yulianto. (2019). Pengujian Technology Acceptance Model Pada Mobile Banking Sebagai Determinan Performa UMKM di Kota Makassar. Jurnal Bisnis \& Kewirausahaan Vol 8 No 3, hal. 251- 261. p-ISSN: 2252-3037, eISSN:26220806. 